\title{
The Minbar:
}

\section{Symbol of Verticality and of Elevation}

\author{
by Naima Chikhaoui
}

Revised, translated and edited by Fatima Jane Casewit

\section{The Sacred Space of the Mosque}

The mosque is the symbol of the living faith of Islam: its religiosity, faith in God and in His all-powerfulness. This sacred space is a reflection of deep belief in the divine word. It is also the place of the offering of prayer and of all the rites and rituals of Islam. To these symbolic elements must be added the components of the sacred space of the mosque: the minaret, the prayer hall with its mibrâb (prayer niche) and the minbar, or pulpit. These are the ritual supports of the sanctity of the mosque. Each of these elements has its own function in the sacred order. The prayer hall is the place of piety and of devotion. The minaret and the minbar represent elevation towards Heaven for the call to prayer or for ritual supplication and/or for the ritual "sermon" or the kbutba. ${ }^{1}$ The divine word is either "proclaimed aloud", or it is silent prayer. To reach God Most High one must either rise, or else prostrate.

The centre of centres can only be God, and the mosque is situated in the centre of space, the more elevated spaces being symbolically nearer to God. Thus, in Islamic tradition the Kaa'ba, the centre of the world, is, symbolically, the most elevated place on earth, symbolising the centre of Heaven. All mosques are considered equivalents or copies of the Kaa'ba.

Centrality and elevation, therefore, are two major aspects of the sanctity of the space of the mosque. Mystical and spiritual communication

1 "Within the mosque, the pulpit may be considered as an extension of the minaret..., both in virtue of its elevation and because it is the domain of truth." Lings, Martin, Symbol and Archetype: A Study of the Meaning of Existence, QuintaEssentia, 1991, pp. 123-124. (translator's addition). 
takes place in a sacred "centre". This communication is expressed through religious rites, rites of "ascension", revealing the process of elevation towards Heaven, of the worship of God.

In the Muslim religion, various ritual symbols assist the believer on his/ her path to Paradise. The ritual prayer, or the "rising" towards the Kaa'ba, or the pilgrimage, are amongst the most well known forms. All of these rites express but one desire, to "rediscover" God, to regain the lost Paradise. The rites involve sacred words which translate the "nostalgia for Paradise" and the love of God. Simply stated, these words use the paths laid out by the religion for access to Heaven.

\section{The Minbar as Ritual Furniture}

One of the supports for this sacred word is the minbar, or the preaching pulpit, the form of which is unique to the Muslim religion. The minbar transmits the word of God, the wise and just words, through the raised voice of the imam, the preacher. The use of the minbar has its origins in the early years of Islam and has remained linked to the ritual of the khutba, sermon, and of the ritual supplication of the Amir Al Mou'minin, the prince of the faithful, and of his good, believing subjects. The tradition is closely linked to speech, and especially to the communication between God and His faithful servants. As mentioned above, all prayers or ritual speech are ascension towards God, and the minbar is the sacred object most adapted to this function of elevation towards Heaven. Tarik Waly describes the minbar as an intermediary between the material and the spiritual worlds.

The minbar is our earthly expression of the integration between the material and the spiritual. It is the feature in mosque architecture to which the believer turns when he needs to reach out mentally through human thought. Thus the mibrâb and the minbar have been two integral parts of Islamic belief which have deviated from all previous elements, as they couple religion with the world. ${ }^{2}$

\section{Symbolism and Features of the Minbar}

What are the features and the symbolism of the minbar which contribute to this function of elevation from the material to the spiritual?

Revealing its etymological relationship to loftiness, the word minbar

2 Waly, Tarek, In Quest of the Path: To "The One" in Mosque Architecture, Beit Al Quran Publications, Bahrain, 1993, p. 82 (translator's addition) 
comes from the root $n b r$, which means to "be high" or "lofty". The verb nabara is used for everything that is raised, and in its original significance it means to mark with a guttural stop. ( $\mathrm{bamza}$ ) The nabr for the Arabs meant to raise the voice, and a man who was known as a nabaar was an eloquent man, clear, lucid and probing. The minbar is the chair of the one who preaches the sermon. It is thus named for its raised position.

The designation of the minbar as a pedestal or elevated support is linked to the history of the preaching chair, or pulpit, itself. The kbatîb, or preacher, addressing the believers, remained standing or sitting on top of it. This tradition was followed by the Prophet Mohammed (saws). A place was reserved for him in the mosque of Medina, usually near a palm tree which was used as a column for the mosque. ${ }^{3}$ The trunk of the palm tree was subsequently cut, forming an elevated seat on which the Prophet sat amidst the faithful. Elevation and loftiness, therefore, has always defined this piece of furniture.

The height of the preaching pulpit can range from $3.5 \mathrm{~m}$ to $3.86 \mathrm{~m}$ which is the height of the famous minbar of the Kutubiyya mosque in Marrakesh. ${ }^{4}$ The preferred building material used in pulpits is wood. The minbar of the Prophet was also called a'wadd, wood in Arabic, referring to the material from which it was built. Wood was used because it is a light material, making the minbar easy to move around. There are other minbars ( pl. manabir) in the Islamic world that have been built with various materials such as marble, stone, ${ }^{5}$ even iron. ${ }^{6}$ The chair usually consists of a back, a canopy, a voice carrier, and a stairway. The stairway is the most symbolic element of the minbar. It varies from seven to nine steps in height. It is said that the Prophet's pulpit was made up of only two steps. ${ }^{7}$

\footnotetext{
Encyclopédie de l'Islam, 1986, p. 74-75

4 The orientalist literature related to the minbar in Islam reports that the mosque of Samara had a minbar which was $3.90 \mathrm{~m}$ high.

5 The oldest manabir (pl. of minbar) were all in wood. Those in marble or in stone seem to be common during the Ottoman period. The North African manabir are generally made of wood. In East Africa, many more manabir are found made of stone.

6 During the Umayyad era, a minbar was often built with iron.

7 This is the minbar of the Prophet placed on a pedestal of six degrees in the mosque of Medina. During the Prophet's time, this minbar only had two steps and a seat. Abu Bakr, Omar and Othman used it in the same way. Mu'away added six steps to it.
} 
The minbar, or pulpit, has always been the object of great care and aesthetic refinement. The decoration of the side walls of the minbar range from geometric, naturalistic and floral patterns to arabesque. The delicacy of the arcades that decorate the entrance bear witness to the value and importance of this ritual and liturgical piece of furniture.

The location of the minbar in the sacred space of the mosque is as important as its loftiness and height. The minbar is generally situated against the qibla wall, (the direction of Mecca), in the central part of the prayer room, to the right of the mibrâb (the niche indicating the qibla) - a centre in a centre. A small room or a large niche is reserved for the minbar, and it is only brought out for the khutba (sermon). It often rests on two small wheels, allowing it to be pulled. ${ }^{8}$ Mobile manabir seem to be rare, but the splendid minbar of the Kutubiyya mosque in Marrakesh is proof of their existence.

With all the details and the various elements that go into it, the minbar is one of the most important elements of the mosque. Although it varies in style and decoration from one Islamic country to another, or from one historical era to another, the minbar remains the same in its function and its liturgy, as well as in its symbolism, all over the Islamic world. It is this vertical symbolism and liturgy which reveal at once the profound "function" of the minbar.

\section{The History of the Function of the Minbar}

The history of the tradition of the minbar reveals its original "double" function, being the proclamation of either a religious or a political speech. The unity of this function resides in a desire and a will to "cry aloud" a speech of Justice, of love of the Truth. This speech was always and still is a sermon about the place of God, the Infinitely Just, and a supplication for His mercy and for His compassion.

The traditional Islamic sermon is a purely objective formulation of doctrine and of law based on the Qur'an and the sayings of the Prophet. The preacher becomes the mouthpiece of these two sources, his subjectivity being as it were extinguished, the more so since the pulpit is so constructed that his face is hidden from most of the congregation. ${ }^{9}$

8 This type is particular to the Maghreb where the manabir were mobile and movable. The minbar of the Kaa'ba was on wheels which allowed it to be pushed from its storage area in the Makam Ibrabim to the Kaa'ba for the Friday sermon.

9 Lings, Martin, Symbol and Archetype: A Study of the Meaning of Existence, Quinta Essentia, 1991, pp. 123-124 
The minbar was firstly the seat of the Prophet in his function as Sabib ArRisâlah, the Messenger, and the Spokesman of God on Earth, to whom the sacred text was revealed. The Prophet (saws) would sit on his minbar to address the community, to show them the right path that leads to Paradise, the way of the believer. He would also share with the community the great decisions related to jihad, holy war, for the Muslim Umma (community) united around the Haqq, the Truth, the supreme and just word of God.

Following the example of the Prophet (saws), the great rulers of Islam subsequently used the minbar to address the community. This tradition lasted until the kbutba, or sermon, was restricted to religious exhortations, and then the minbar became the pulpit of the preacher, the raised pulpit, from which the beautiful words are pronounced, words calling for devotion and worship of God. The function of the minbar is, therefore, essentially religious, and it is because of this that the minbar is found all over the Muslim world. This common function is reinforced by the same symbolism and liturgy expressed by the minbar.

What meanings and symbolism does the minbar represent and how is it used for rituals? Being an integral part of the mosque, the minbar is a sacred object, or piece of liturgical furniture. It belongs to a sacred space which is not tread upon except with bare feet, marking off the profane space from the sacred. But the "perceptive space" occupied by the minbar is very special. Its central location and raised position allow it to dominate and to capture the glance and attention of all those assembled. This is emphasised by the raised voice of the preacher. This particular "perceptive space" condenses a representative symbolism that takes its meaning from the element of elevation. The height of the minbar is marked by the presence of a staircase. The elevation often expressed by a ladder or stairway is one of the most ancient designs of ascension. ${ }^{10}$ This design is always linked to the symbolism of verticality, a sign of purity and of height. The raised minbar is therefore a symbol of the spiritual "verticality" and of metaphysical completion. A sacred and elevated piece of

10 "The ladder thus puts before us a very complete symbolism: it can be likened to a vertical bridge rising throughout the worlds and making it possible to traverse their whole hierarchy by passing from rung to rung; and at the same time the rungs are the worlds themselves, that is, the different levels or degrees of universal Existence." René Guénon, Fundamental Symbols, The Universal Language of Sacred Science, QuintaEssentia, Cambridge, 1995 (translator's edition) 
furniture, it permits one to take on this verticality for oneself, towards "height", leading to light.

\section{Height and Light}

This aspiration and thrust towards height and light respond to both a spiritual and psychological tendency, based on the complimentarity of the pattern of elevation and the visual archetype of light. It is this human aspiration which is at the origin of dynamic images of ascension. Moreover, the primordiality of the vertical image can be added to the upright position and the accompanying psychological tendency that is unique to human beings. Only a minbar, or a ladder, rising towards the Elevated and the Almighty, can reach verticality synonymous with purity and the supreme goal.

The minbar, in its symbolism of verticality, can be added to other significant rituals of ascension in other civilizations. The ceremonial staircase, the initiatic ladder, the arduous ascent, the cosmic tree, ${ }^{11}$ and of course the elevated kaa'ba are a few examples of this symbolism of verticality. The symbols of ascension, of which one is the minbar, mark a spiritual verticality that can only be obtained by rising towards Heaven above the platitudes of the flesh and of profane space. In the spiritual life, the believer is called upon to move from one world to another. When the preacher mounts the minbar, he stands up straight and leans on his sceptre and proclaims the "holy" word, addressed in the name of God. His words transcend the space of this lower world and go directly to the celestial space. It is not only a question of a change in space, but as M. Eliade remarks, it is even a question of changing one's mode of being:

...the staircase is the bearer of an extremely rich symbolism, without ceasing to be perfectly coherent: it explicitly shows the rupture in level which makes possible the passage from one mode of being to another. ${ }^{12}$

\section{The Khatîb, or Preacher}

The preacher, a man of great faith, raises his voice carrying the word of

\footnotetext{
${ }^{11}$ The Prophet stood next to a tree or next to the trunk of a palm tree. The tree is related to the symbolism of life, to the unceasing evolution and ascension towards Heaven. The tree also conveys all the symbolism of verticality. The tree always captures the light of the sky.

12 Eliade, M. Images et Symboles, Tel/Gallimard, Paris, 1980, p. 63
} 


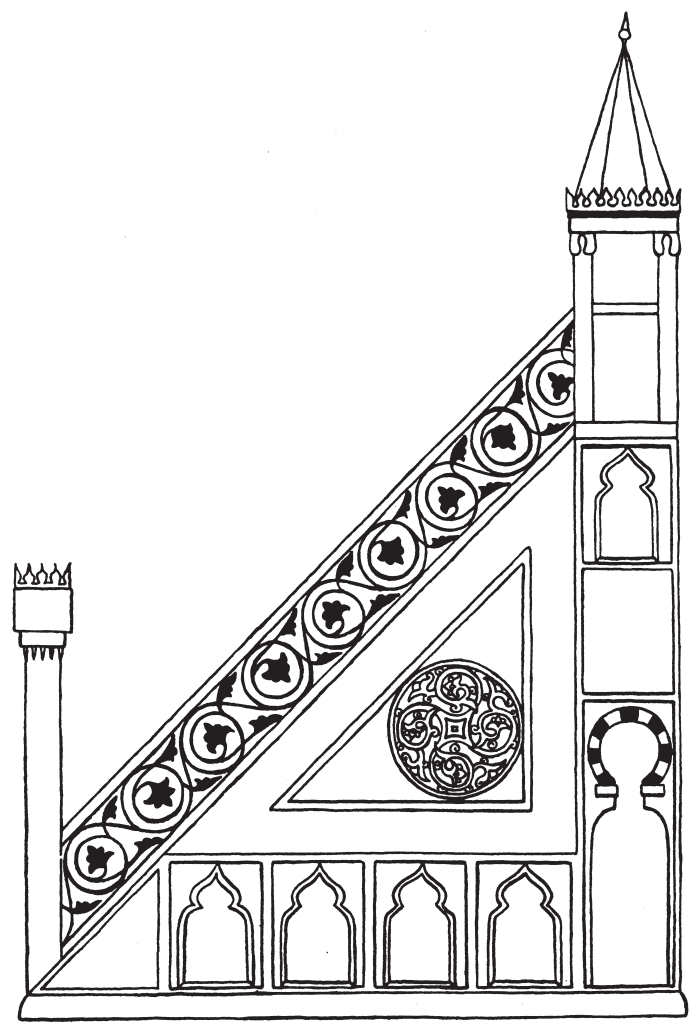

The pulpit (Minbar), viewed from the side of a staircase passage.

God, the Infinitely Just and Almighty. He lives a moment of unity with the divine word which he communicates to other believers, calling on them to worship God and to spread His message on earth. In Arab culture, upon hearing a prayer, one says "from your mouth to the gate of Heaven." The spiritual and psychological aspiration of the preacher for purity, as a spokesman of a group of believers, is therefore prefigured in the loftiness of the minbar, rising up through the seven or nine steps, symbols of the seven divine heavens." 13

\footnotetext{
${ }^{13}$ For an in-depth explanation of symbolism see Symbol and Archetype, A Study of the Meaning of Existence, by Martin Lings, Quinta Essentia, Cambridge, 1991 (translator's note)
} 
The tradition of $\mathrm{A} l \mathrm{Khataba}$, or delivering sermons, actually predates Islam. But there is a clear difference between $\mathrm{A} l$ Khataba of the ancient Arabs and that which developed in the Islamic era. During the time of the Jâbilîyah, the pre-Islamic era, the khatîb was the spokesman of the tribe. He stood beside the poet and defended the tribe against other enemies. The duty of the khatîb demanded a perfect mastery of the Arabic language and a clear and correct pronunciation of the letters and of the words. The kbatîb expressed himself in prose, often in the form of rhymed prose, or saja' $a$, and rarely used poetic verses. The $k b a t i \hat{b}$ was known to be a courageous man who was at once a horseman and fighter.

With the event of Islam, the kbutba, or sermon, became exclusively a religious and/or political speech addressed to Muslims inside the mosque. The ancient custom of mufâkbirab ${ }^{14}$ or intertribal boasting and vain glory, was abandoned and replaced by a religious sermon, and later of course by the panegyric of the caliphs, defenders of Islam. It was during the Abbasid period that the khutba, the sermon, became purely religious. It took place in Medina, on a Friday, and in only one mosque.

By elevating the khatîb, the minbar accomplishes its profound function and permits the word of God to rise in a vertical direction. If "all of spiritual life is expressed by an ascent" the place of the minbar in sacredness and ascension is primal.

\section{The Symbolism of the Steps}

In the person of the khatîb, the word of the Truth, Al Haqq, ascends the steps of the minbar just as the souls of the just ascend up a ladder towards Heaven. Was not the Night Ascension of the Prophet Mohamed (Mi'râj) an ascent up a celestial ladder? The steps of the minbar are also significant of this process of ascension.

As a general rule steps are of odd numbers: 3, 7, 9, and 11. Muslim mysticism speaks of three levels and states that the initiate must attain in order to be united with Al-Haqq, the Truth or Allah: the level of purification, then of illumination, and finally Unity. The tradition of the three steps respects the practice of the Prophet (saws). Manabir with 11 steps,

${ }^{14}$ The Mufâkhirab carried the meaning of spurring the populace to war. The Qurayshî tribes practiced it with fervour, boasting of their honour, nobility and power through poems. The main objective of this almost ritual practice was collective exaltation. See Encyclopédie de l'Islam, vol. VIII, pp. 311-312. 
fairly rare, remain faithful to the notion of rupture and of passage. Ten steps open up a new way to the $11^{\text {th }}$ which is the "passage". The three, seven or nine steps are an expression of totality, of achievement. These latter numbers have ritual value, and they therefore symbolise the crowning of efforts and a tendency towards "the final Truth." Seven and nine express the celestial spheres or the seven or nine heavens, through which it is necessary to cross in order to reach Divine light. Once the seven steps are crossed, one arrives at the eighth level which is that of equilibrium and justice. Eight steps are rarely used in manabir.

Other meanings found in Islamic esoterism concerning the numbers 7 and 9 are the seven or nine senses or subtle centres of man (the seven intelligences) which allow ascension towards Heaven. In other words, the seven spiritual states exist in a hierarchy that makes possible the passage from earth to Heaven. ${ }^{15}$

The supreme function of the minbar, therefore, is to be a bond and an intermediary between earth and Heaven. The minbar provides elevation for the word or promise of Paradise, of pardon, and of love of God. The elevation is furnished by steps which are symbolic in their number. This function, accomplished by a piece of ritual furniture, is accomplished by a man who is central in Muslim liturgy, the khatîb and/or the imam. It is worth noting that the khatîb only ascends as far as the middle step on the minbar, not to the top, and always remains standing as he preaches as an act of devotion and submission to the Prophet (saws). ${ }^{16}$

\section{The Khutba}

The kbutba then became a religious rite for Fridays, the feast of Al Fitr (marking the end of the sacred month of Ramadan) and the feast of $A l$ Adha, (the feast of the sacrifice) a khutba is also usually given at the time of a koussouf (eclipse) and for the prayer of alistikssa (prayer for rain). However, when necessary, the khutba often remained linked to politics. The decrees and the great political decisions, until a late date, took effect following their pronouncement from the top of the minbar.

The kbutba was normally restricted to the ceremonial occasion of the

\footnotetext{
15 The 7 circumambulations or the 7 ritual gestures appear often in Islamic liturgy: 7 circumambulations of the Kaa'ba, the 7 visits or Ziyârât of a saint, etc.

${ }^{16}$ From a photographic display accompanying the Kutubiyya minbar in Marrakesh (translator's addition).
} 
Friday prayer but its ritual always remained the same. In pronouncing the $k b u t b a$, or sermon, the kbatîb has retained his main symbolic accessories, which, in addition to the minbar includes the ceremonial baton. These are honorific accessories, symbols of power and authority. The common features of these two objects - Al 'Uudan - the sceptre and the minbar, are wood and verticality. In response to the mockery that the Persians made about the use of the sceptre, Al Djahiz ${ }^{17}$ mentions the qualities marking the nobility of wood and of the use of sceptre. He also mentions the symbolism of power and strength.

\section{Honorific Accessories of the Khatib and his Khutba}

The wooden sword and the sceptre, or the baton, have since Roman times, been a sign of authority and of divine justice. The sceptre is also a symbol of pure verticality. Thus, the sceptre of the khatîb should not contain any defect (Al Djahiz). The verticality of the sceptre or of the wooden sword is also linked to the symbolism of power. It fits with the elevation of the minbar, because "elevation and power are in effect synonyms." ${ }^{18}$ Another element can be added to these attributes, which Al Djahiz calls "the mechanism of the word"19 or the voice. The raised voice of the preacher preaches and proclaims the "word" of God and of divine justice.

The ritual of the kbutba is not complete without the respect given to the khatîb's dress. According to Al Ghazali, the clothes of the khatîb should be white. White ${ }^{20}$ is another sign of purity, of transparence and of light. These various elements making up the ritual and its meaning are also a source of authority and of sovereignty for the khatîb. Does one not touch the clothing of the kbatîb in search of baraka (spiritual radiance)? The kbatîb who climbs up the minbar in a white robe, holding the baton in his right hand, crosses a sacred space par excellence and pronounces a stirring religious sermon. A kbutba that does not begin with gratitude towards God or tabmid is, for the ancient kbutaba', an "amputated" or mutilated (batra) sermon. A sermon without Koranic

\footnotetext{
${ }^{17}$ Al Djahiz, Al Bayân wa Tâbi î̀n, Librairie Nouvelle, Beirut, Volume I, 1968, p. 58

${ }_{18}^{18}$ Ibid.

19 Ibid.

${ }^{20}$ White used in vestments is part of Islamic tradition of sacred rites and space. The white worn on the pilgrimage is symbolic of purity and a return to primordiality.
} 
verses and without a reminder of the Prophet (saws) is considered "ugly" or "hideous". ${ }^{21}$

The Islamic kbutba, therefore, is a ritual of prayer and of worship of God. The Friday prayer assembling a large number of the faithful and celebrated in all the mosques expresses this love and the begging of forgiveness on the part of the believers. This bursting out of faith is expressed in noble and sacred words, the communion of the faithful, and their communication with the Almighty. Only the minbar, soaring toward Heaven, is capable of conveying this "mystical" and metaphysical aspiration of Muslims in the name of the khatib, the perpetual servant of God. It is also for all these reasons that the minbar has always been the subject of special veneration. Does one not caress the minbar in pursuit of baraka, spiritual radiance? Women sometimes hang small pieces of cloth on the back of the minbar as supports for personal prayer, to take advantage of this baraka. It is therefore not surprising that the minbar has preserved its primordial place in Islamic liturgy and in the sacred space of the mosque.

The great sanctity of the minbar is drawn from this sacred centre, which is the mosque. Within the sanctuary of the mosque, the supreme function of the minbar is the ascension towards the Almighty.

\section{The Sublime Minbar of the Kutubiyya Mosque in Marrakesh}

Beginning in the lifetime of the Prophet Mohammed (saws) the minbar became a fundamental part of the sacred space of the mosque. Muslims throughout the ages have spared no effort and exploited the utmost creativity to embellish their manabir. One of the most exquisite examples of this piece of liturgical furniture is the minbar of the Kutubiyya Mosque in Marrakesh. This magnificent piece is considered one of the most accomplished works of Islamic art. In all its splendour and decorative beauty, this famous minbar reflects the apogee of the power of the Almoravid and Almohad dynasties, as well as their religious fervour. Both dynasties devoted themselves to the defence of religion as a noble duty and as a solid basis of their religious power. The minbar of the Kutubiyya mosque is a prime example of the ascending and lofty symbol proclaim-

\footnotetext{
${ }^{21}$ Al Djahiz, Al Bayân wa Tibyin, Librairie Nouvelle, Beirut.
} 
ing great faith in God. ${ }^{22}$ In addition to its decoration, which continually draws the viewer inward, the great peculiarity of this minbar is the probable rare and ingenious mechanism which accompanied it.

This wooden masterpiece was built by an Andalusian builder in Cordoba named Al-Hajj Ya'is between approximately 1139 and 1142 CE. It was commissioned and constructed during the reign of Ali ibn Yousef ibn Tasfin (reigned 1106-1143) during the Almoravid dynasty, and was meant for the Sultan Ali's mosque in the capital of the empire. When completed, the minbar was shipped in parts to Marrakesh and assembled for the Sultan's mosque. However, a short time later, in 1147, 'Abd Al Mu'min defeated the Almoravids and conquered Marrakesh and immediately built a new mosque, the present Kutubiyya, on the site of Ali's palace. The minbar was moved into this mosque and was used for eight centuries until it was removed for restoration in the mid 1990s.

Besides its rich decoration, the other striking feature of this piece was that it functioned mechanically like the maqsoura (wall separating the sultan from the congregation) and the Qur'an stand in the same mosque. This elevated seat is a remarkable witness to the mastery of mobile mechanisms of the $12^{\text {th }}$ century. The minbar, standing on wooden wheels, silently and automatically slid from its lodge to the prayer room. This was done at the same time as the walls of the maqsoura rose from the floor by means of the same mechanical system. ${ }^{23}$ A system of counterweights and ropes, hidden in a depression located in front of the door of the closet where the minbar was kept, were used. This industrious and flexible mechanism incited awe in the faithful and drew the attention of the great historians and poets. Describing the maqsoura, Abu Bakr b. Mujbar al-Himyari al-Fihri, said:

It surrounds those who are in its centre Like a wall amongst the walls,

And at the same time it escapes their looks Like a secret among secrets ${ }^{24}$

22 "Within the mosque, the pulpit may be considered as an extension of the minaret...in virtue of its elevation and because it is the domain of truth." (Lings, Martin, Symbol and Archetype: A Study of the Meaning of Existence, QuintaEssentia, 1991, pp. 123-124) (translator's addition).

23 "It was done with a system of cables, pulleys and tambourines, lifted by a counter weight" Deverdun, G. Marrakech des Origines à 1912, pp. 176-177

${ }^{24}$ Excerpt from the Hulal and Mouchia, Meunié J. and Terass, H., Recherches archéologiques à Marrakesh, 1952 p. 47 
The dimensions of the minbar of the Kutubiyya are also impressive. It measures 3.86 metres high, is .87 metres wide and 3.46 metres deep, and is among the highest of the manabir, if not the highest. It is also the minbar which brings together the most sophisticated and varied of decorative techniques known in the Muslim world. This HispanoMoorish pulpit exhibits the peak of Arab-Muslim ornamentation. It integrates techniques of ivory inlay work and precious woods, of floral mosaic inlay work and sculpted calligraphic decoration. The inlay work of red and yellow sandal-wood, of ebony, of ivory, and of aloe, accentuates its splendour.

A chronicler of the Almoravid and Almohad dynasties described this sublime piece as "a monumental minbar...of perfect accomplishment."25

In addition to its aesthetic and decorative value, the calligraphy has a very strong ritual value. In Islamic tradition, various texts and writing are usually inscribed into manabir, on the walls of the mosque and on the mibrâb, three sacred spaces/objects which express the spiritual functions of the minbar and their relation to the sacred space of the mosque.

The minbar, a sacred ladder, placed in the sacred centre, is a symbolical means by which praise and prayer reach to Heaven. The just word rises to Heaven by the degrees of the minbar just as the souls of the righteous will be raised up on a celestial ladder under the gaze of the Prophet Mohammed (saws). Sacred words reach beyond this world. The various formulae of prayer are inscribed on the minbar through faith in the value of the sacred word and the spiritual height symbolised by liturgical furniture.

The minbar of the Kutubiyya mosque is no exception to this tradition. The prayers and verses from the Qur'an engraved onto this piece of liturgical furniture summarise the sacredness and the solemnity of this majestic pulpit:

Lo! Your Lord is Allah Who created the heavens and the earth in six Days, then mounted He the Throne. He covereth the night and the day, which is in haste to follow it, and hath made the sun and the moon and the stars subservient by His command. His verily is all creation and commandment. Blessed be Allah, the Lord of the Worlds!

(Qur'an 7:54 - "The Heights")

\footnotetext{
${ }^{25}$ From the pictoral history of the Kutubiyya minbar on display in the Badia' Palace, Marrakesh (translator's note).
} 
Allah! There is o God save Him, the Alive, the Eternal. Neither slumber nor sleep overtaketh Him. Unto Him belongeth whatsoever is in the heavens and whatsoever is in the earth. Who is he that intercedeth with Him save by His leave? He knoweth that which is front of them and that which is behind them, while they encompass nothing of His knowledge save what He will. His Throne includeth the heavens and the earth, and He is never weary of preserving them. He is the Sublime, the Tremendous.

(Qur'an 2:255 - "The Throne Verse" in "The Cow") ${ }^{26}$

\section{An inscription on top of the back rest reads:}

"This minbar was made in the city of Cordoba, may God protect it, for this venerated congregational mosque, may God make it endure with the world of Islam." 27

The minbar has been beautifully restored by the Metropolitan Museum of Art, New York and the Ministry of Cultural Affairs of Morocco, thanks to a grant offered by Ms. Patti Cadby Birch. The original minbar, with an accompanying photographic exhibition and history, is on display in the Badia' Palace in Marrakesh.

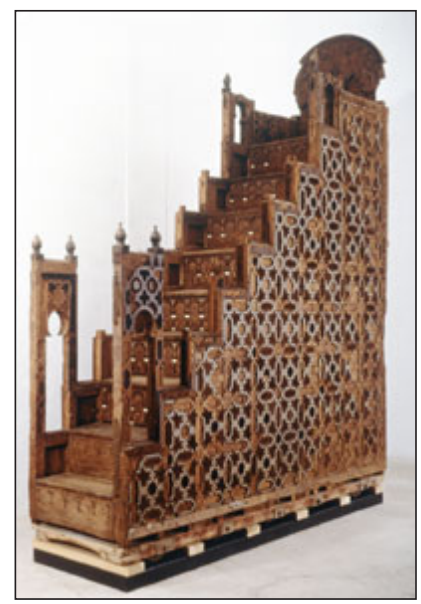

Detail of the minbar from the Kutubiyya Mosque in Marrakesh. Metropolitan Museum of Art.

${ }^{26}$ Mohammed Marmaduke Pickthall translation of the Qur'an, Festival of Islam publication, London, 1976 (translator's addition).

27 Taken from photographic display of the restoration process of the minbar in the Badia' Palace, Marrakesh (translator's addition). 


\section{Bibliography}

Al Djahiz, Al Bayan wa Tabyin, Beirut, 1968 (3 volumes)

Chevalier, J., Gheerbrant, A. Dictionnaire des Symboles, Paris 1982

Deverdun, G. Marrakech des origins à 1912, vol. 1, Rabat 1952

Durand, G. Les Structures anthropologiques de l'imaginaire, Paris 1984

Eliade, M., Images et symbols, Paris 1980

Eliade, M., Le Mythe de l'éternel retour, Paris, 1969

Eliade, M., Traité d'histoire des religions, Paris 1975

Leiden, E., Brill, J., Encyclopédie de l'Islam, t. IV, VII, Paris 1983

Mélanges d'histoire et d'archéologie de l'Occcident musulman. Hommage à G. Marçais, t. I, Alger, 1957

Meunié, J., Terrasse, H., Recherches archéologiques à Marrakech, Paris 1952 Sauvaget, J. "Le minbar de la koutoubia de Marrakech", dans Hespéris, 3ème-4ème tr. 1949 , pp. $313-319$

\section{Translator's Bibliography}

Lings, Martin, Symbol and Archetype: A Study of the Meaning of Existence, QuintEssentia, Cambridge, U.K., 1991

Waly, Tarek, In Quest of the Path: To "The One" in Mosque Architecture, Beit Al Quran Publiations, Bahrain, 1993

Guénon, René, Fundamental Symbols, The Universal Language of Sacred Science, QuintaEssentia, Cambridge, UK, 1995 